\title{
Ageing and the Attainment of Form in Robinson Crusoe
}

\author{
LUCIA FOLENA, UNIVERSITY OF TURIN
}

In the initial lines of "Sailing to Byzantium" (L1. 1-10) William Butler Yeats opposes youth - as a time of existential plenitude and full immersion in the joys of carnality and sense - to the irresistible physical decay brought about by the process of growing old. An awareness of this spoliation, however, does not necessarily entail only loss and despair. For the gradual ebbing away of corporal faculties leaves increasing ground for the intellectual and spiritual progresses of the "soul" (L. 11), to the point where it becomes possible to imagine a final metamorphosis of the passionate and transient living body into a detached and eternal artistic masterpiece graced with an absolute perfection of form. ${ }^{1}$ Thus, paradoxically, ageing may turn into an aesthetic experience. And there are cases in which, instead of positing the antithetical nature of the two terms involved - 'life' and 'art' in its definitively lifting the individual him/herself out of the pathway of the former up to the sanctuary of the latter, such an experience results in reducing or denying the opposition by directly transfiguring one of the terms into the other: converting the whole existential itinerary that has produced the now-aged individual into an aesthetically and intellectually gratifying object.

Any creative product invested with an aesthetic function - as well as art in general, including literature - may be regarded as an attempt to impose

1 Frank Kermode stresses that Yeats's “artifice of eternity" is a striking periphrasis for "form"' (2000: 3). 
form and legibility - i.e., 'meaning' - upon the chaotic, irrational, ultimately unreadable, fluidity of life. But 'art' is not always the outcome of a deliberate intervention on the raw materials of existence; it is also the natural point of arrival of life itself, since it is precisely the latter's fluidity that generates, in the course of time, the possibility of its being transcended, 'dynamic' confusion eventually freezing into 'static' order, harmony, and peace.

On one level, a narrative, regardless of its specific characteristics, is always and invariably an account of the process through which its protagonist gets hold of form, finally acquiring the hindsight that enables him/her - and/or the reader - to pronounce a conclusive statement on his/her experiential itinerary, which at that point has lost the inevitable fragmentariness of its former day-to-day development to display itself as a continuous line, no matter how circuitous, conducting from beginning to end. ${ }^{2}$ This characteristic, however, becomes decidedly more prominent in the early novel, which is structurally dependent on it, partly at least on account of the usually greater length of the time span covered - years, decades, occasionally a whole lifetime, whereas previous narratives (with the notable exception of the picaresque) often limit themselves to the recounting of one or few momentous adventures or episodes in the protagonist's existence.

The 18th-century English novel constructs a new kind of subjectivity based on a linear notion of time. Like the early novel, late-medieval and early-modern romances also often foreground discovery, and selfdiscovery, as a central object of the character's action, but in that case what comes to light eventually, rather than appearing as the creation of time, trial, error, and commitment, manifests itself as having already been there, though hidden - as having been constantly present in a state of latency. It is in the novel that the final discovery gets equated with the awareness of 'new' components having added themselves to one's individuality.

2 In the words of Georg Lukács (1971: 80), the "inner form of the novel" is "the process of the problematic individual's journeying towards himself, the road from dull captivity within a merely present reality - a reality that is heterogeneous in itself and meaningless to the individual - towards clear selfrecognition. After such self-recognition has been attained, the ideal thus formed irradiates the individual's life as its immanent meaning." 
The Old Man (far more rarely the Old Woman) is a recurrent figure in medieval narratives, especially in chivalric romances. He does not usually appear as a protagonist, nor does he get directly involved in the action whose military and athletic character obviously calls for physical exuberance, ardent vigor and the kind of naïve assurance that is ascribed to the prime of youth - but he still plays a fundamental, twofold role vis-à-vis the central character, acting simultaneously as counselor and interpreter. In this second function he also integrates a metatextual component designed to instruct the reader. For not only does he (intratextually) palliate with his sage advice the inexperience and lack of foresight which are seen as typifying the earlier phases of human life; he provides (both intra- and extratextually) indispensable contributions to the unfolding of the true 'sense' or 'meaning' of events and adventures. Without him the story he gets involved in would remain at least partly obscure or ambiguous in its implications. ${ }^{3}$

The first English novel - for, all in all, Robinson Crusoe undoubtedly deserves that label - attributes to the Old(er) Man an analogous form of wisdom: the ability to see beyond appearances and predict the negative consequences of younger people's inappropriate conduct or unrestrained desires. The father's interdiction - an extreme, authoritarian rather than merely authoritative variant of the Old Man's counsel despite the affection for the son he displays and the tears he sheds - takes up the opening of the narrative and works as the initial catalyst of its action (Defoe 2007: 5-8). ${ }^{4}$ There the eighteen-year old is quite significantly entreated "not to play the young Man" (7), as if it were possible for him to divest himself of an age which endows him with the very traits that make him a credible potential adventurer and, in effect, a far more coherent up-and-coming capitalist than his overly prudent interlocutor. ${ }^{5}$ No "young Man" governed by restlessness

3 Cp. Todorov 1977: 120-42.

4 That this is no mere advice but an actual veto is stressed immediately afterwards by the father himself, in his dialogue with the mother: "That Boy might be happy if he would stay at home, but if he goes abroad he will be the miserablest Wretch that was ever born: I can give no Consent to it." (Defoe 2007: 8; emphasis added)

5 Ian Watt observes that "the argument between his parents and himself is a debate, not about filial duty or religion, but about whether going or staying is 
and desire, no story. Felix culpa: as in the biblical account of the Fall, an "original sin" of disobedience (Defoe 2007: 164) must needs inaugurate events and prefigure their development in terms of a gradual bridging of the gap between son and father through the agency of time and experience.

Just a few pages later another Old Man intervenes with his judicious warnings in an equally unsuccessful attempt to change the course of the protagonist's insubordinate existence:

Young Man, says he, you ought never to go to Sea any more, you ought to take this for a plain and visible Token that you are not to be a Seafaring Man [. . .]. And young Man, said he, depend upon it, if you do not go back, where-ever you go, you will meet with nothing but Disasters and Disappointments till your Father's Words are fulfilled upon you. (Defoe 2007: 14-15; original emphasis)

Robinson's unwillingness to take such advice - the impossibility, in fact, for him at that early stage of being to do so - marks one primary difference between the novel and its predecessor, the romance. The Young Man can no longer adopt his older counterpart's view sic et simpliciter: he must literally convert himself into the Old Man in order to be able to see things that way. He must ripen from Son into Father, as Robinson symbolically does not only by growing in years and judgment but by 'educating' Friday. ${ }^{6}$ Such a metamorphosis evidently entails an extensive and painful itinerary through life and experience. It requires, first and foremost, a large amount of time, the chronicle of which is precisely the main theme of the tale. The new 'Grail' of the novel coincides with the second function assigned to the

likely to be the most advantageous course materially: both sides accept the economic argument as primary. And, of course, Crusoe actually gains by his 'original sin', and becomes richer than his father was". Watt adds that such an "original sin" is actually "the dynamic tendency of capitalism itself, whose aim is never merely to maintain the status quo, but to transform it incessantly" (1957: 64).

6 "[N] ever Man had a more faithful, loving, sincere Servant, than Friday was to me; without Passions, Sullenness or Designs, perfectly oblig'd and engag'd; his very Affections were ty'd to me, like those of a Child to a Father; and I dare say, he would have sacrific'd his Life for the saving mine, upon any occasion whatsoever" (Defoe 2007: 176; emphasis added). 
elderly mentor in the romance - that of revealing hidden meanings. This has become the object of a lifelong quest whereby it is no longer a secondary character but the hero who gains the power of interpretation and explains to the reader the consequences and significations of his younger self's errors and misfortunes.

This kind of evolution might be regarded as not entirely new, considering that a very ancient narrative such as Beowulf already, and rather uncharacteristically, features a protagonist who is fifty years older at the end than in his inaugural confrontations with Grendel and his mother, and on whom time has bestowed wisdom as well as renown - the aristocratic counterpart of the bourgeois respectability that Robinson eventually conquers. There is, however, an enormous difference between the Anglo-Saxon epic and the 18th-century novel. First and foremost, the time separating Beowulf's initial and final adventures is far from being treated as worthy of more than a cursory mention, which takes up just three out of the poem's 3182 lines. When Hygelac, the previous king of the Geats, dies,

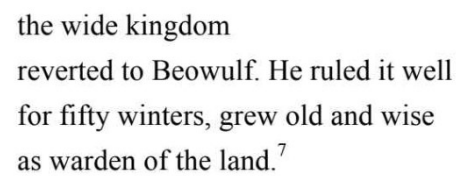

The narrator then hastens on to the final battle with the dragon. Furthermore, Beowulf"s growing "old and wise" does not seem to have really changed him much. His prowess has remained unaltered, and so has his pride, which is what prevents him - against the prudence he is supposed to have gained - from seeking the help of his warriors in facing the phenomenally dreadful enemy (L1. 2345-47), and thus leads him to his heroic death. The only difference between the young hero and his elderly upshot therefore resides in the inevitable physical deterioration that has taken place in the half-century interval.

When the protagonist of Robinson Crusoe starts his autobiographical account, he is about seventy-two years old, having been born in 1632, as he informs the reader at the very beginning of the novel, while his final words

7 L1. 2207-10 (Beowulf 2000: 151). 
state that he has been carrying on an existence rich in "surprizing Incidents" and "new Adventures" for "ten Years more" after his 1694 voyage "as a private Trader to the East Indies" (Defoe 2007: 257-58; original emphasis). It is evidently only in that advanced phase of his life that he feels he has acquired the detachment and perspective necessary to reconstruct all that preceded it as a continuous and teleological progression in time, arranging meaningful splinters of past events into a coherent, causal sequence. Only now has he at last become a master of form, a creator/discloser - one who can produce legible shapes out of the primal chaos of human reality as well as reveal the pattern hidden in that chaos and explain its implications. Reaching such a stage is like attaining a summit whence one may survey the whole of the itinerary which has led to it, and 'refigure' it as a historically-determined progression. ${ }^{8}$

First-person narratives, especially when fashioned as fictional autobiographies like those of Daniel Defoe, are particularly dependent on this motif. When the account, rather than coming directly from the subject of the experiences reported, is delivered by an external voice, the imposition of 'meaning' on existential disorder is partly - often largely allocated to it, while the lack of another figure of mediation between text and reader in stories told by their supposed protagonists turns the latter into their own exegetists and moralizers. Hence their lives become not only quests for happiness and a place in the world, but routes through an anarchic, incomprehensible proliferation of unrelatable phenomena towards a final attainment of form and unity - an attainment which coincides with the end of the story and the coming of old age. The early novel, at least in Defoe's hands, is thus the story of how, in the progression of time, a common, undistinguished human being immersed in a flux of events ultimately achieves narratorial authority and the power of endowing the tale told with emblematic significance.

8 For refiguration, or "mimesis 3", cp. Ricoeur 1984: 52-87. Refiguration is the outcome of an act of reading, so that it is generally presupposed by a text as its potential and necessary destination, but not contained in it - not actualized until that text enters the domain of reception. Now autobiography - no matter how fictional - incorporates, to a far larger extent than any other narrative form, an enactment of that very process by the protagonist, who presents him/herself as the first reader of his/her past experiences. 
The novel as such presupposes not only the centrality of time as an agent of change, but a way of relating to time that differs profoundly from that which characterized previous narrative forms. It is, as a matter of fact, a wholly new concept of temporality that comes into play here. Ian Watt opposes the Platonic view permeating ancient philosophy and literature to the modern one surfacing in the Renaissance but manifesting itself fully only with the rise of the novel. For in Shakespeare as well as in Spenser, and still in Bunyan, "the sequence of events is set in a very abstract continuum of time and space, and allows very little importance to time as a factor in human relationships" (Watt 1957: 22). ${ }^{9}$

The Platonic outlook, in its positing Ideas, which were "timeless and unchanging", as "the ultimate realities behind the concrete objects of the temporal world", gave time a very limited role in determining worldly events and affairs (Watt 1957: 20-21). Even more widely influential, the traditional Christian viewpoint characteristic of the Middle Ages, despite its differing from the classical one in its setting up a "quantitative rather than a qualitative difference between time and eternity" (Le Goff 1980: 31), concurred with it in denying the crucial function of time in shaping the itinerary towards salvation: "for the Christian in the Middle Ages [...] to feel his existence was to feel his being, and to feel his being was to feel himself not changing, not succeeding himself in time, but subsisting" (Poulet 1956: 3-4). Moreover, Christian time belonged to God only and humans had no right to sell and buy it. ${ }^{10}$

9 Analogously, Jacques Le Goff points out that the late-medieval "epic and gest were $[\ldots]$ negations of history by feudal society, which used historical items only to strip them of historicity in the context of an atemporal ideal" (1980: 32). In the courtly romance, whose "fundamental purpose" is a "self-portrayal of feudal knighthood with its mores and ideals", as Erich Auerbach emphasizes, "the indications of time are as reminiscent of fairy tale as the indications of place" (2013: 130-31). On the simultaneity of past and present in Arthurian romance, cp. also Todorov 1977: 134

10 Le Goff cites the way in which a $14^{\text {th }}$-century Franciscan lector-general settled a dispute on this issue: "Question: is a merchant entitled, in a given type of business transaction, to demand a greater payment from one who cannot settle his account immediately than from one who can? The answer argued for is no, 
Around the 12 th century the increasing social weight of the mercantile middle class and the needs of the rising commercial capitalism, the very existence of which depended on the appropriation and marketability of time, began opening up a drastically new perspective in which time itself was gradually transformed into a measurable and monetarily evaluable commodity. Rather than mutually exclusive, Church time and commercial time then became complementary, as belonging to two distinct spheres of reality - the spiritual and the pragmatic. The Christian merchant started dividing his life into two separate segments, making Church time into "a second horizon of his existence": the "time in which he worked professionally was not the time in which he lived religiously. Where salvation was concerned, he was content to accept the Church's teaching and directives" (Le Goff 1980: 37). It was only, however, between the late 17 th and the early 18 th century, when the middle class started supplanting the aristocracy in terms of ideological hegemony over the rest of society, offering it its own values and beliefs as universal principles to be espoused by all, that this major change became apparent in literature, turning into one of the decisive components of the new, bourgeois fiction identified as the novel.

In Robinson Crusoe the presence of time is constantly perceptible and often explicitly drawn attention to. The very first line of the narrative outlines the protagonist's identity in terms of when - and where - his existence began, and only after that inaugural characterization are his social and national origins specified: "I Was born in the Year 1632, in the City of York, of a good Family, tho' not of that Country [...]." (Defoe 2007: 5) The reader is later recurrently, scrupulously informed about the years, and even the months and presumed days, that have elapsed since the outset of Crusoe's "strange surprizing adventures", and eventually assured that the measurement effected by the protagonist was largely if not entirely accurate: "as for an exact Reckoning of Days, after I had once lost it, I could never recover it again; nor had I kept even the Number of Years so punctually, as to be sure that I was right, tho' as it prov'd, when I afterwards examin'd my Account, I found I had kept a true Reckoning of Years." (Defoe 2007: 209) He had in fact, at the very beginning of his stay

because in doing so he would be selling time and would be committing usury by selling what does not belong to him" (1980: 29; original emphasis). 
on the island, erected a kind of monument to the succession of temporal splinters he expected to live through:

I cut it with my Knife upon a large Post, in Capital Letters, and making it into a great Cross I set it up on the Shore where I first landed, viz. I came on Shore here on the 30th of Sept. 1659. Upon the Sides of this square Post I cut every Day a Notch with my Knife, and every seventh Notch was as long again as the rest, and every first Day of the Month as long again as that long one, and thus I kept my Kalander, or weekly, monthly, and yearly reckoning of Time. (Defoe 2007: 55-56; original emphasis)

Furthermore, Robinson's constant, uninterrupted preoccupation with time may be symbolized in the name he imposes on the young native he saves from the anthropophagic designs the members of another tribal group have on him - the name of a fraction in his personal history, a day of the week:

I made him know his Name should be Friday, which was the Day I sav'd his Life; I call'd him so for the Memory of the Time; I likewise taught him to say Master, and then let him know, that was to be my Name. (Defoe 2007: 174; original emphasis)

Through this double baptism he of course also defines his future rapport with the newcomer, establishing once and for all his own superiority over him. ${ }^{11}$ But the symbolism involved in enclosing a person's identity in the name of a day perhaps extends to the choice of "Master" as a selfappellation. When measured and segmented into a sequence of units which are differentiated and rendered unique by the specific positions they occupy vis-à-vis other units - time turns from a mysterious, impersonal and overpowering entity controlling people's lives into something manageable, capable of being mastered and governed, and 'makes sense' to humans thanks to the 'syntactic' reorganization the self-same separating gesture produces on the newly-identified components.

The Journal incorporated in the retrospective narration (Defoe 2007: 60-113) offers a further tangible attestation of the constant need Robinson experiences to measure time and to establish a precise correspondence between days and events - "to minute down the Days of the Month on

11 Cp. Novak 1997: 117; Keane 1997: 115. 
which any remarkable Thing happen'd to me" (113) - thus simulating and thematizing that "reinscription of phenomenological time onto cosmological time", to use Ricoeur's formula (1988: 180-182), which is one salient feature of novel-writing and of the historiographical modality that it imitates. The intelligibility of life and the world, then, depends on a double gesture: demolition - the dissection of time entrusted to the Young Man in his progress through the events - must precede that activity of (re)construction which is only accessible to the Old Man.

Division and differentiation occur on all levels, from the macroscopic one of years and seasons (Defoe 2007: 90-91) to the microscopic one of daily activities assigned to precise hours (97-98). This temporal fragmentation matches the spatial one that gradually turns the originally indistinct, unknown body of the Island of Despair (Defoe 2007: 60) into the anthropized, syntactically organized territory of a colony - however scantly peopled - as in an ideal step-by-step transformation of the land into its own map. Essentially, the stretch of time involved in this process gets subjected to a remarkably similar mapping process. Such a twofold charting may be taken to suggest, metatextually, the pioneering work of the bourgeois writer colonizing narrative space and time for his own class. It also functions as a general metaphor of human life, in a Lockean psychological ontogenesis of sorts where the "white paper"12 in the new-born human's mind mirrors and duplicates the temporal and spatial tabula rasa outside him/her: for 'falling' into life is like finding oneself in an unfamiliar region - in time and space that one, little by little, has to take possession of and to make meaningful to oneself. Old age is the phase when the exploration is more or less complete and a map may be drawn on the basis of a process of refiguration. It is as if, when he reaches his island after the shipwreck, Robinson is 'born again', in both literal and religious senses; and the account of the initial phases of his new existence shows that the steady acquisition of knowledge and manual and intellectual skills he experiences is absolutely inseparable from the spiritual and moral growth that leads him to recognize and honor God's presence in himself and in the physical world around him. Analogously, within the basic pattern of linearity which underlies the representation of time as an agent of change in this novel - and in the large majority of its descendants - the temporal syntax the narrator sets up reintroduces a form

12 Locke 2017: 18. 
of circularity that in all likelihood, rather than looking back to the romance, secularizes the biblical prototype and the practice of the typological interpretation of scriptural history, where past, present and future are intrinsically connected, to the point of being essentially homogeneous if not identical, by the recurrence of events or figures whose entire meanings are only elucidated in juxtaposition. ${ }^{13}$ The narrator makes the curvature explicit through declaring, "I remember that there was a strange Concurrence of Days, in the various Providences which befel"; examples of those temporal coincidences are provided immediately afterwards (Defoe 2007: 113). ${ }^{14}$ As happens very visibly in Moll Flanders (Watt 1957: 97-98), and indeed in many other passages of Robinson Crusoe, here two voices are anachronistically merged: that of the Young Protagonist who is gradually discovering the 'figure in the carpet' of his earthly adventure, and that of the Aged Narrator - the wise, discerning old person who sees the whole picture retrospectively and is in a position to explain the implications and connections of events in light of what came to pass afterwards. ${ }^{15}$

13 For this kind of interpretation, which originated in the early centuries of Christianity and was still in use in Protestant contexts at the beginning of the $18^{\text {th }}$ century, cp. Auerbach 1994. This connection with typology is part of Robinson Crusoe's more general dependence, in structure as well as content, on the model of the Puritan narrative and the spiritual autobiography. The novel "is structured on the basis of a familiar Christian pattern of disobedience punishment-repentance-deliverance, a pattern set up in the first few pages of the book" (Hunter 1966: 19).

14 "First I had observed, that the same Day that I broke away from my Father and my Friends, and run away to Hull, in order to go to Sea; the same Day afterwards I was taken by the Sallee Man of War, and made a Slave. The same Day of the Year that I escaped out of the Wreck of that Ship in Yarmouth Rodes, that same Day-Year afterwards I made my escape from Sallee in the Boat. The same Day of the Year I was born on (viz.) the 30th of September, that same Day, I had my Life so miraculously saved 26 Year after, when I was cast on Shore in this Island, so that my wicked Life, and my solitary Life begun both on a Day." (Defoe 2007: 113; original emphasis)

15 This juxtaposition of points of view is also suggested by the wavering recourse to present and past tenses in the passage: "I [now, while writing this story] 
The combination of those two distant points of view is particularly frequent in the Journal, despite its being initially presented as an accurate reproduction of the actual logbook Young Crusoe produces before running out of ink. At the same time at which this section enters the text as a body of documental evidence aimed at confirming the veridical nature of its account, it introduces a significant fissure, if not an outright contradiction, into the otherwise solid autobiographical makeup of the story. In general, diaristic and epistolary novels tend to appear as 'configurations', or 'emplotments', rather than refigurations, of experience: ${ }^{16}$ the first-person narrator is not in a position to see beyond the episode he/she is relating, or its immediate reverberations, so as to foretell the direction his/her existential itinerary is actually taking and to disclose the 'meaning' and 'shape' it bears; and in the absence of the Interpreter embodied by the Old(er) Protagonist in an autobiographic tale, or by a third-person narrator in other novelistic forms, the same uncertainty is shared by the reader. Contrariwise, in Robinson Crusoe the day-by-day record often gives way to reflections and moral judgments that are clearly only possible a long while ex post facto. One of the most manifest examples of Old Robinson's sermonizing intrusions is provided by his severe comments on Young Robinson's past obstinacy in repeatedly rejecting both his father's good

remember [ . . . the] strange Concurrence of Days" versus "I had observed [then, while experiencing each second episode which recalled a previous one]." (ibid)

16 Ricoeur derives the notion of emplotment from Aristotle and explains it thus: "Plot is mediating in at least three ways. First, it is a mediation between the individual events or incidents and a story taken as a whole. In this respect, we may say equivalently that it draws a meaningful story from a diversity of events or incidents (Aristotle's pragmata) or that it transforms the events or incidents into a story. The two reciprocal relations expressed by from and into characterize the plot as mediating between events and a narrated story. As a consequence, an event must be more than just a singular occurrence. It gets its definition from its contribution to the development of the plot. A story, too, must be more than just an enumeration of events in serial order; it must organize them into an intelligible whole, of a sort such that we can always ask what is the 'thought' of this story. In short, emplotment is the operation that draws a configuration out of a simple succession" (Ricoeur 1984: 65). 
advice and God's help before the "terrible Dream" of the man with the spear (Defoe 2007: 75-78).

Such relentless counseling is of course perfectly useless, for neither the protagonist nor the reader may accept that kind of guidance. To both of them the genre of the novel, as 'invented' by Defoe, opens up territories which they must needs discover for themselves, no matter how often those regions have already been explored by their elders. 'Form' and the power of interpretation are no longer legacies to be handed down from one generation to the following: they have turned into the very goals of their protagonists' quests.

\section{BIBLIOGRAPHY}

Auerbach, Erich (1994 [1938]): "Figura". In: Erich Auerbach, Scenes from the Drama of European Literature, trans. Ralph Manheim, Minneapolis: Univ. of Minnesota Press, pp. 11-76.

Auerbach, Erich (2013 [1946]): Mimesis: The Representation of Reality in Western Literature. Trans. Willard R. Trask, Princeton: Princeton UP.

Beowulf (2000). Trans. Seamus Heaney, New York-London: Norton.

Defoe, Daniel (2007 [1719]): Robinson Crusoe. Ed. Thomas Keymer, Oxford-New York: Oxford UP.

Hunter, J. Paul (1966): The Reluctant Pilgrim: Defoe's Emblematic Method and Quest for Form in Robinson Crusoe, Baltimore: Johns Hopkins UP.

Keane, Patrick (1997): "Slavery and the Slave Trade: Crusoe as Defoe's Representative". In: Roger D. Lund (ed.), Critical Essays on Daniel Defoe, New York: G. K. Hall, pp. 97-120.

Kermode, Frank (2000 [1966]): The Sense of an Ending: Studies in the Theory of Fiction, Oxford-New York: Oxford UP.

Le Goff, Jacques (1980 [1977]): “Merchant's Time and Church's Time in the Middle Ages". In: Jacques Le Goff, Time, Work, and Culture in the Middle Ages. Trans. A. Goldhammer, Chicago-London: The University of Chicago Press, pp. 29-42.

Locke, John (2017 [1689-90]): An Essay Concerning Human Understanding, Book 2. Ed. J. Bennett. Last accessed March 6, 2018 (http://www.earlymoderntexts.com/assets/pdfs/locke1690book2.pdf). 
Lukács, Georg (1971 [1920]): The Theory of the Novel. Trans. Anna Bostock, Cambridge, Mass.: MIT Press.

Novak, Maximilian (1997): "Friday: Or, The Power of Naming". In: Albert J. Rivero (ed.), Augustan Subjects: Essays in Honor of Martin C. Battestin, Newark: University of Delaware Press, pp. 110-122.

Poulet, Georges (1956): Studies in Human Time. Trans. Elliott Coleman, Baltimore: Johns Hopkins UP.

Ricoeur, Paul (1984, 1985, 1988 [1983, 1984, 1985]): Time and Narrative, 3 vols. Trans. K. McLaughlin and D. Pellauer, Chicago: The University of Chicago Press.

Todorov, Tzvetan (1977 [1971]): The Poetics of Prose. Trans. Richard Howard, Ithaca - London: Cornell University Press.

Watt, Ian (1957): The Rise of the Novel, Berkeley-Los Angeles: University of California Press.

Yeats, William Butler (1989): "Sailing to Byzantium". In: A. Norman Jeffares (ed.), Yeat's Poems, London: Gill and Macmillan, pp. 301-302. 